\title{
MOTIVASI DAN DISIPLIN KERJA PENGARUHNYA TERHADAP KINERJA PEGAWAI KANTOR REGIONAL $X$ BADAN KEPEGAWAIAN NEGARA DENPASAR MELALUI LINGKUNGAN KERJA SEBAGAI VARIABEL INTERVENING
}

\author{
Wayan Arya Paramarta ${ }^{1}$, Komang Budi Arnawan ${ }^{2}$ \\ ${ }^{1-2}$ Program Studi Manajemen \\ Sekolah Tinggi Ilmu Manajemen Indonesia Handayani Denpasar \\ aryaajus@gmail.com
}

\begin{abstract}
Human resource management should build disciplinary behaviour for employees who compete competitively in the current era of globalization. Besides, with the existence of human resource management, it is expected that they have to create the best performance for companies that want to advance or develop, so they are required to have quality employees. The purpose of this study was to analyses the influence between motivation and work discipline on employee performance at the Regional Office X Denpasar State Civil Service Agency through the work environment as an intervening variable. The type of data used in this study is qualitative data and quantitative data, with data sources namely data. primary and secondary. The data collection method was carried out by distributing questionnaires to respondents, while the data analysis method in this study used Partial Least Square (PLS) with Smart PLS version 3.2.9. The results of this study indicate that motivation has a positive but insignificant effect on employee performance, work discipline has a positive but insignificant effect on employee performance, motivation has a positive and significant effect on the employee work environment, work discipline has a positive and significant effect on the employee work environment, work environment. positive and significant effect on employee performance. Furthermore, motivation has a positive but not significant effect on performance through the work environment of employees, work discipline has a positive and significant effect on performance through the work environment of the employees of Regional Office X Denpasar State Civil Service Agency.
\end{abstract}

Keywords : Motivation, Work Discipline, Work Environment, and Employee Performance

\begin{abstract}
ABSTRAK
Manajemen sumber daya manusia memiliki kewajiban untuk membangun perilaku disiplin pegawai yang bersaing kompetitif di era globalisasi sekarang. Disamping itu dengan adanya manajemen sumber daya manusia diharapkan memliki tugas untuk menciptakan kinerja terbaik bagi perusahaan yang ingin maju atau berkembang maka dituntut untuk memiliki pegawai yang berkualitas. Tujuan dari penelitian ini adalah untuk menganalisis pengaruh antara motivasi dan disiplin kerja terhadap kinerja pegawai pada Kantor Regional X Badan Kepegawaian Negara Denpasar melalui lingkungan kerja sebagai variabel intervening, Jenis data yang digunakan dalam penelitian ini adalah data kualitatif dan data kuantitatif, dengan sumber data yaitu data primer dan sekunder. Metode pengumpulan data dilakukan dengan menyebarkan kuesioner kepada responden, sedangkan metode analisis data dalam penelitian ini menggunakan Partial Least Square (PLS) dengan Smart PLS versi 3.2.9. Hasil penelitian ini menunjukkan bahwa, motivasi berpengaruh positif tetapi tidak signifikan terhadap kinerja pegawai, disiplin kerja berpengaruh positif tetapi tidak signifikan terhadap kinerja pegawai, motivasi berpengaruh positif dan signifikan terhadap lingkungan kerja pegawai, disiplin kerja berpengaruh positif dan signifikan terhadap lingkungan kerja pegawai, lingkungan kerja berpengaruh positif dan signifikan terhadap kinerja pegawai. Selanjutnya motivasi berpengaruh positif tetapi tidak signifikan terhadap kinerja melalui lingkungan kerja pegawai, disiplin kerja berpengaruh positif dan signifikan terhadap kinerja melalui lingkungan kerja pegawai Kantor Regional X Badan Kepegawaian Negara Denpasar.
\end{abstract}

Kata Kunci: Motivasi, Disiplin Kerja, Lingkungan Kerja dan Kinerja Pegawai

\section{PENDAHULUAN}

Potensi sumber daya manusia tersebut perlu dikembangkan dan diperhatikan agar menjadi sumber daya manusia yang profesional dan berkualitas sehingga berdampak pada keberhasilan perusahaan. Pegawai yang berkualitas adalah pegawai yang kinerjanya dapat memenuhi target atau sasaran yang ditetapkan oleh perusahaan (Handoko, 2011). Untuk mencapai kinerja 
yang maksimal, maka perusahaanharus mampu menciptakan kondisi yang dapat mendorong dan memungkinkan karyawan untuk mengembangkan dan meningkatkan kemampuan serta keterampilan yang dimiliki secara optimal.

Faktor yang menjadi bagian penting dalam kehidupan organisasi adalah motivasi. Motivasi karyawan dipengaruhi oleh berbagai faktor baik faktor internal maupun eksternal. Faktor internal yang mempengaruhi motivasi kerja karyawan berasal dari unsur-unsur yang timbul dari karyawan itu sendiri sebagai aktualisasi diri seperti, minat pekerja, kemauan, kemampuan dan tanggung jawab. Faktor eksternal motivasi kerja karyawan berupa kesejahteraan karyawan, lingkungan kerja, pendidikan, penghargaan, pelatihan kerja dan masih banyak lainnya (Sutrisno, 2014).

Paramarta, dkk (2018) menyatakan bahwa motivasi dan disiplin kerja berpengaruh signifikan terhadap kinerja karyawan. Utomo (2014) menyatakan bahwa motivasi mempunyai pengaruh negatif terhadap kinerja, sedangkan kepemimpinan, displin dan lingkungan mempunyai pengaruh positif terhadap kinerja.

Kantor Regional X Badan Kepegawaian Negara (BKN) Denpasar merupakan salah satu kantor pelayanan administrasi atau manajemen kepegawaian dari dua belas Kantor Regional yang ada di Indonesia. Oleh karena itu, disiplin kerja pegawai pada Kantor Regional X Badan Kepegawaian Negara (BKN) Denpasar akan sangat berpengaruh terhadap keberhasilan pengelolaan administrasi kepegawaian di wilayah kerjanya. Maka konsekuensinya Kantor Regional X Badan Kepegawaian Negara (BKN) Denpasar harus mampu memenuhi hak dan tanggung jawab untuk melaksanakan tugas dan pelayanan yang lebih baik kepada pegawai daerah dan pegawai pusat yang ada di daerah wilayah kerjanya dan juga kepada masyarakat yang membutuhkan pelayanan kepegawaian.

Pokok masalah yang diajukan dalam penelitian adalah bagaimana pengaruh motivasi dan disiplin kerja terhadap kinerja pegawai yang dimediasi oleh lingkungan kerja di Kantor Regional X Badan Kepegawaian Negara Denpasar. Sedangkan yang menjadi tujuan dalam penelitian ini adalah untuk menjelaskan pengaruh motivasi dan disiplin kerja terhadap kinerja pegawai yang dimediasi oleh lingkungan kerja di Kantor Regional X Badan Kepegawaian Negara Denpasar.

\section{METODOLOGI PENELITIAN}

\section{Lokasi Penelitian}

Penelitian ini dilakukan di Kantor Regional X Badan Kepegawaian Negara Denpasar yang beralamat di Jalan By Pass Ngurah Rai No 646 Pedungan dengan responden pegawai di Kantor Regional X Badan Kepegawaian Negara Denpasar.

Definisi Operasional Variabel

Menurut Sugiana (2008) adalah batasan pengertian tentang variabel yang didalamnya sudah mencerminkan indikatorindikator yang digunakan untuk mengukur variabel yang bersangkutan. Untuk melihat operasional suatu variabel tersebut harus diukur dengan menggunakan indikatorindikator yang dapat memperjelas variabel yang dimaksud. Adapun yang menjadi definisi operasional dalam penelitian ini adalah sebagai berikut:

1. Motivasi adalah pemberian daya penggerak yang menciptakan kegairahan kerja seseorang pegawai di Kantor Regional X Badan Kepegawaian Negara Denpasar agar mereka mau bekerja sama, bekerja efektif dan terintegrasi dengan 
segala daya upayanya untuk mencapaikepuasan, dengan indikator (Sitohang, 2007):
a. Pendorong
b. Membentuk keahlian
c. Ketrampilan
d. Membentuk Karakter
e. Emosional

2. Disiplin kerja adalah suatu sikap menghormati, menghargai, patuh dan taat terhadap peraturan-peraturan yang berlakubagi pegawai di Kantor Regional X Badan Kepegawaian Negara Denpasar baik yang tertulis maupun tidak tertulis serta sanggup menjalankannya dan tidak mengelak untuk menerima sanksisanksinya apabila ia melanggar tugas dan wewenang yang diberikan kepadanya, dengan indikator (Robbins, 2006):
a. Tepat waktu
b. Disiplin peraturan
c. Tanggung jawab
d. Tertib
e. Disiplin waktu

3. Lingkungan Kerja adalah keseluruhan alat perkakas dan bahan yang dihadapi, lingkungan di Kantor Regional X Badan Kepegawaian Negara Denpasar dimana seseorang bekerja, metode kerjanya, serta pengaturan kerjanya baik sebagai perseorangan maupun sebagai kelompok, dengan indikator (Robbins, 2006):

a. Tepat waktu

b. Disiplin peraturan

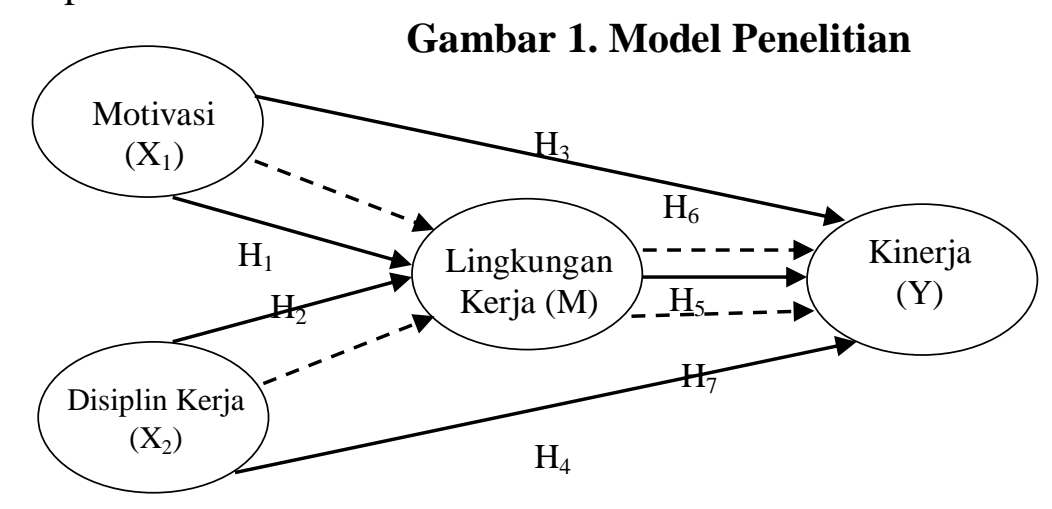

c. Tanggung jawab
d. Tertib
e. Disiplin waktu

4. Kinerja merupakan hasil pekerjaan yang mempunyai hubungan kuat dengan tujuan strategis organisasi, kepuasan pegawai di Kantor Regional X Badan Kepegawaian Negara Denpasar dan memberikan kontribusi ekonomi, dengan indikator (John, 2006);
a. Kuantitas
b. Kualitas
c. Efektivitas
d. Kemandirian
e. Komitmen kerja

\section{Populasi dan Sampel}

Populasi adalah gabungan dari seluruh elemen yang berbentuk peristiwa, hal atau orang yang memiliki karakteristik yang serupa yang menjadi pusat perhatian peneliti (Ferdinand, 2006). Populasi dalam penelitian adalah seluruh Pegawai Negeri Sipil pada Kantor Regional X Badan Kepegawaian Negara Denpasar yang berjumlah 75 orang. Dalam penelitian ini karena jumlah populasi adalah 75 orang maka keseluruhan populasi akan dipergunakan sebagai responden.

\section{Model Penelitian}

Penelitian ini menggunakan analisis PLS dengan dua variabel bebas dan dua variabel terikat, dimana satu variabel merupakan variabel intervening. Berikut model dalam penelitian ini: 


\section{Teknik Pengumpulan Data}

Dalam penelitian ini peneliti menggunakan teknik pengumpulan data berupa penyebaran kuisioner atau angket. Kuesioner/angket adalah teknik pengumpulan data yang dilakukan dengan cara memberikan seperangkat pertanyaan atau pernyataan kepada orang lain yang dijadikan responden untuk dijawabnya. Dari kuesioner dapat dihasilkan hasil jawaban yang disebarkan kepada responden.

\section{Teknis Analisis Data}

Setelah data terkumpul dari lapangan, selanjutnya dilakukan pengolahan terlebih dahulu agar data yang tersebar luas dalam item-item kuesioner dapat dibuat lebih ringkas dan lebih sederhana dengan bantuan program IBM SPSS Statistics 22. Selanjutnya, analisis dilakukan agar data mentah yang diperoleh di lapangan mempunyai arti dan makna sehingga dapat menjawab permasalahan yang diajukan, analisis data dalam penelitian ini dilakukan dengan menggunakan Smart PLS 3.2.9.

\section{HASIL DAN PEMBAHASAN}

\section{Uji Validitas dan Reliabilitas}

Uji validitas digunakan untuk mengetahui penafsiran responden terhadap setiap butir pertanyaan/pernyataan yang terdapat dalam instrumen penelitian. Uji validitas dilakukan kepada responden dengan menggunakan analisis korelasi product moment. Bila nilai korelasi product moment tiap instrumen tersebut positif dan besarnya 0,3 ke atas maka indikator tersebut dapat dikatakan valid.

Uji reliabilitas dilakukan untuk menguji penafsiran responden mengenai butir-butir pertanyaan/pernyataan yang terdapat dalam instrumen penelitian yang ditunjukkan dengan konsistensi akan jawaban yang diberikan. Nilai batas yang dipergunakan untuk menilai sebuah tingkat reliabilitas yang dapat diterima adalah sebesar 0,60 .

Tabel 1. Hasil Output Uji Validitas dan Reliabilitas Instrumen

\begin{tabular}{|c|c|c|c|c|}
\hline Variabel & $\begin{array}{l}\text { Cronbach's } \\
\text { Alpha } \\
\end{array}$ & Indikator & \begin{tabular}{|l|} 
Koefisien \\
Korelasi \\
\end{tabular} & KeT \\
\hline \multirow{5}{*}{$\begin{array}{l}\text { Motivasi } \\
(\mathrm{X} 1)\end{array}$} & \multirow{5}{*}{$\begin{array}{l}0,587 \\
\text { (Reliabel) }\end{array}$} & Pendorong & $0,660 * *$ & Valid \\
\hline & & Keahlian & $0,726 * *$ & Valid \\
\hline & & Keterampilan & $0,657 * *$ & Valid \\
\hline & & Karakter & $0,614 * *$ & Valid \\
\hline & & Emosional & $0,466 * *$ & Valid \\
\hline \multirow{5}{*}{$\begin{array}{l}\text { Disiplin } \\
\text { (X2) }\end{array}$} & \multirow{5}{*}{$\begin{array}{l}0,772 \\
\text { (Reliabel) }\end{array}$} & Tepat Waktu & $0,664 * *$ & Valid \\
\hline & & \begin{tabular}{|l|} 
Peraturan \\
\end{tabular} & $0,808 * *$ & Valid \\
\hline & & Tanggung Jawab & $0,709 * *$ & Valid \\
\hline & & Tertib & $0,703 * *$ & Valid \\
\hline & & Disiplin Waktu & $0,740 * *$ & Valid \\
\hline \multirow{5}{*}{$\begin{array}{l}\text { Lingkungan } \\
\text { Kerja (X3) }\end{array}$} & \multirow{5}{*}{$\begin{array}{l}0,596 \\
\text { (Reliabel) }\end{array}$} & Penerangan & $0,474 * *$ & Valid \\
\hline & & Peralatan & $0,707 * *$ & Valid \\
\hline & & Bising & $0,551 * *$ & Valid \\
\hline & & Keamanan & $0,679 * *$ & Valid \\
\hline & & Hubungan & $0,725 * *$ & Valid \\
\hline \multirow{5}{*}{$\begin{array}{l}\text { Kinerja } \\
(\mathrm{Y} 1)\end{array}$} & \multirow{5}{*}{$\begin{array}{l}0,443 \\
\text { (Reliabel) }\end{array}$} & Kualitas & $0,546^{* *}$ & Valid \\
\hline & & Kuantitas & $0,620 * *$ & Valid \\
\hline & & Efektivitas & $0,670 * *$ & Valid \\
\hline & & Kemandirian & $0,476^{* * *}$ & Valid \\
\hline & & Komitmen & $0,493 * *$ & Valid \\
\hline
\end{tabular}

Sumber: Data diolah

Berdasarkan rekapitulasi hasil perhitungan nilai korelasi product moment dari tiap-tiap item pertanyaan/pernyataan pada tabel 1, diperoleh hasil yang besarnya di atas 0,3. Hal ini berarti semua butir pertanyaan/pernyataan dalam kuesioner tersebut dapat dikatakan valid. Berdasarkan rekapitulasi hasil perhitungan nilai cronbach's alpha dari masing-masing variabel pada tabel 1 diperoleh hasil yang besarnya di atas 0,60. Hal ini berarti semua variabel dalam kuesioner tersebut dapat dikatakan reliabel.

\section{Hasil Analisis Inferensial}

Dalam penelitian ini, teknik analisis data yang digunakan adalah PLS dengan program Smart PLS 3.2.9. Berdasarkan hasil pengolahan data menggunakan PLS, selanjutnya mengevalusai model persamaan struktural. Dalam evaluasi ini terdapat dua evaluasi mendasar, yaitu: (1) evaluasi model pengukuran (outer model) untuk mengetahui validitas dan reliabilitas indikator-indikator yang mengukur variabel laten, dan (2) evaluasi model struktural (inner model) untuk 
mengetahui ketepatan model. Sebelum evaluasi model dilakukan, dapat ditegaskan kembali bahwa instrumen penelitian (kuisioner) sebagai alat pengumpul data adalah instrumen yang valid dan reliabel.

\section{Evaluasi Model Pengukuran (Outer Model)}

Evaluasi model pengukuran memeriksa validitas dan reliabilitas indikatorindikator yang mengukur konstruk atau variabel laten. Dalam penelitian ini keempat variabel laten, yaitu: Motivasi $\left(\mathrm{X}_{1}\right)$, Disiplin Kerja $\left(\mathrm{X}_{2}\right)$, Lingkungan Kerja (M) dan Kinerja (Y) merupakan model pengukuran dengan indikator reflektif, sehingga dalam evaluasi model pengukuran dilakukan dengan memeriksa convergent dan discriminant validity dari indikator, serta composite reliability untuk blok indikator.

a. Menilai Outer Model atau Measurement Model

Terdapat tiga kriteria di dalam penggunaan teknik analisis data dengan Smart PLS untuk menilai outer model yaitu Convergent Validity, Discriminant Validity dan Composite Reliability. Convergent Validity dari model pengukuran dengan refleksi indikator dinilai berdasarkan korelasi antara itemscore/component score yang di estimasi dengan Software PLS. Ukuran refleksif individual dikatakan tinggi jika berkorelasi lebih dari 0,70 dengan konstruk yang diukur. Namun menurut Ghozali (2006) dalam (Yuteva, 2010) untuk penelitian tahap awal dari pengembangan skala pengukuran nilai loading 0,5 sampai 0,6 dianggap cukup memadai. Dalam penelitian ini akan digunakan batas loading factor sebesar 0,60.

Dalam teknik analisis data dengan menggunakan Smart PLS terdapat tiga kriteria yang digunakan dalam menilai outer model, yaitu Convergent Validity, Discriminant Validity, dan Composite Reliability. Dalam Convergent Validity yang merupakan model dengan menggunakan refleksi indicator yang dinilai berdasarkan korelasi antara item score/component score yang diestimasi dengan software PLS. Kriteria penilaian dalam metodi ini adalah apabila nilai yang dihasilkan > 0,70 maka dapat dikatakan terdapat korelasi dan terdapat refleksi individual dengan konstruk yang diukur. Ghozali (2006) dalam Yuteva (2010) menjelaskan bahwa skala pengukuran nilai loading 0,5 hingga 0,6 dapat dikatakan cukup memadai. Dalam penelitian yang dilakukan oleh peneliti akan ditetapkan kriteria loading factor sebesar 0,60.

Tabel 2. Outer Loadings (Measurement Model)

\begin{tabular}{|l|c|c|}
\hline Variabel/Indikator & Model Awal & Modifikasi \\
\hline Motivasi & 0,833 & 0,837 \\
\hline Pendorong & 0,750 & 0,747 \\
\hline Keahlian & 0,524 & \\
\hline Keterampilan & 0,739 & 0,740 \\
\hline Karakter & 0,105 & \\
\hline Emosional & 0,578 & \\
\hline Disiplin & 0,801 & 0,803 \\
\hline Tepat Waktu & 0,707 & 0,704 \\
\hline Peraturan & 0,714 & 0,719 \\
\hline Tanggung Jawab & 0,805 & 0,804 \\
\hline Tertib & 0,301 & \\
\hline Disiplin Waktu & 0,749 & 0,746 \\
\hline Lingkungan Kerja & 0,432 & \\
\hline Penerangan & 0,770 & 0,783 \\
\hline Peralatan & 0,808 & 0,818 \\
\hline Bising & \\
\hline Keamanan & 0,540 & 0,769 \\
\hline Hubungan & 0,759 & 0,809 \\
\hline Kinerja & 0,805 & \\
\hline Kualitas & 0,275 & \\
\hline Kuantitas & 0,230 & \\
\hline Efektivitas & \\
\hline Kemandirian & \\
\hline Komitmen & \\
\hline Sumber: Data diolah & \\
\hline
\end{tabular}

Sumber: Data diolah

Pengolahan data dengan menggunakan bantuan software Smart PLS dapat dilihat pada tabel 2. Dapat diamati bahwa beberapa instrument variabel memiliki nilai yang dihasilkan pada hasil pengolahan data nilai outer model atau korelasi antar konstruk adalah $<0,60$. Sehingga dilakukan modifikasi 
model dengan membuang indicator variabel yang memiliki nilai $<0,60$. Pada tabel ditunjukkan hasil modifikasi bahwa idikator variabel penelitian telah memiliki nilai $>0,60$ sehingga dapat dikatakan telah memenuhi syarat dan tidak ada indicator variable yang perlu dilakukan eliminasi.

b. Discriminant Validity

Discriminant validity dilakukan untuk memastikan bahwa setiap konsep dari masing-masing variabel laten berbeda dengan variabel lainnya. Model mempunyai discriminant validity yang baik jika setiap nilai loading dari setiap indikator dari sebuah variabel laten memiliki nilai loading yang paling besar dengan nilai loading lain terhadap variabel lainnya. Hasil pengujian discriminant validity diperoleh sebagai berikut:

Tabel 3. Nilai Discriminant Validity (Cross Loading)

\begin{tabular}{|c|c|c|c|c|}
\hline & $\begin{array}{c}\text { Disiplin } \\
\text { Kerja }\end{array}$ & Kinerja & $\begin{array}{c}\text { Lingkungan } \\
\text { Kerja }\end{array}$ & Motivasi \\
\hline Bising & 0.198 & 0,319 & 0,444 & 0,183 \\
\hline Disiplin Waktu & 0,804 & 0,566 & 0,643 & 0,698 \\
\hline Efektivitas & 0,576 & 0,805 & 0,613 & 0,585 \\
\hline Hubungan & 0,525 & 0,691 & 0,818 & 0,396 \\
\hline Karakter & 0,426 & 0,401 & 0,467 & 0,737 \\
\hline Keahlian & 0,570 & 0,403 & 0,468 & 0,749 \\
\hline Keamanan & 0,655 & 0,541 & 0,783 & 0,633 \\
\hline Keterampilan & 0,311 & 0,285 & 0,333 & 0,530 \\
\hline Kualitas & 0,231 & 0,565 & 0,374 & 0,272 \\
\hline Kuantitas & 0,614 & 0,773 & 0,615 & 0,353 \\
\hline Pendorong & 0,578 & 0,537 & 0,500 & 0,833 \\
\hline Peralatan & 0,457 & 0,559 & 0,746 & 0,460 \\
\hline Peraturan & 0,803 & 0,563 & 0,465 & 0,403 \\
\hline Tanggung & 0,704 & 0,505 & 0,450 & 0,450 \\
\hline Jawab & 0,573 & 0,345 & 0,289 & 0,210 \\
\hline Tepat Waktu & 0,719 & 0,520 & 0,551 & 0,546 \\
\hline Tertib & 0,5
\end{tabular}

Sumber: Data diolah

Dari Tabel 3, dapat dilihat bahwa nilai loading factor untuk setiap indikator dari masing-masing variabel memiliki nilai loading factor yang lebih besar dibanding nilai loading jika dihubungkan dengan variabel lainnya. Hal ini berarti bahwa setiap variabel memiliki discriminant validity yang baik.
Dapat disimpulkan pada tabel 3, bahwa hasil perhitungan nilai loading factor untuk setiap indicator dari masing-masing variabel memiliki nilai loading factor lebih besar apabila dilakukan perbandingan dengan nilai loading apabila dihubungkan dengan variabel yang lain. Dari sini dapat disimpulkan bahwa tiap-tiap variabel penelitian telah memiliki discriminant validity yang baik.

c. Mengevaluasi Reliability dan Average Variance Extracted (AVE)

Untuk melihat validitas dan reliabilitas suatu indicator variabel penelitian dapat juga dilihat melalui hasil perhitungan nilai reliabilitas suatu konstruk penelitian dan nilai hasil perhitungan Average Variance Extracted (AVE) yang diperoleh dari masing-masing konstruk. Sebuah konstruk dapat dianggap memiliki nilai reliabilitas yang tinggi apabila memenuhi kriteria >0,70 serta nilai AVE > 0,50 .

Pada Tabel 4, akan disajikan nilai Composite Reliability dan Average Variance Extracted (AVE) untuk seluruh variabel.

Tabel 4. Composite Reliability dan AVE

\begin{tabular}{|l|c|c|}
\hline & $\begin{array}{c}\text { Composite } \\
\text { Reliability }\end{array}$ & $\begin{array}{c}\text { Average Variance } \\
\text { Extracated }(\text { AVE })\end{array}$ \\
\hline Disiplin Kerja & 0,846 & 0,527 \\
\hline Kinerja & 0,762 & 0,522 \\
\hline Lingkungan Kerja & 0,798 & 0,509 \\
\hline Motivasi & 0,809 & 0,520 \\
\hline
\end{tabular}

Sumber: Data diolah

Berdasarkan Tabel 4, dapat disimpulkan bahwa semua konstruk memenuhi kriteria reliabel. Hal ini ditunjukkan dengan nilai composite reliability di atas 0,70 dan Average Variance Extracted $(A V E)$ diatas 0,50 sebagaimana kriteria yang direkomendasikan.

d. Pengujian Model Struktural (Inner Model)

Evaluasi model struktural atau inner model bertujuan untuk memprediksi hubungan antar variabel laten. Model 
struktural dievaluasi dengan melihat besarnya presentase variance yang dijelaskan yaitu dengan melihat nilai R-Square untuk konstruk laten endogen dan Average Variance
Extracted (AVE) untuk predictivenness dengan menggunakan prosedur resampling seperti jackknifing dan bootstrapping untuk memperoleh stabilitas dari estimasi.

\section{Gambar 2. Model Struktural}

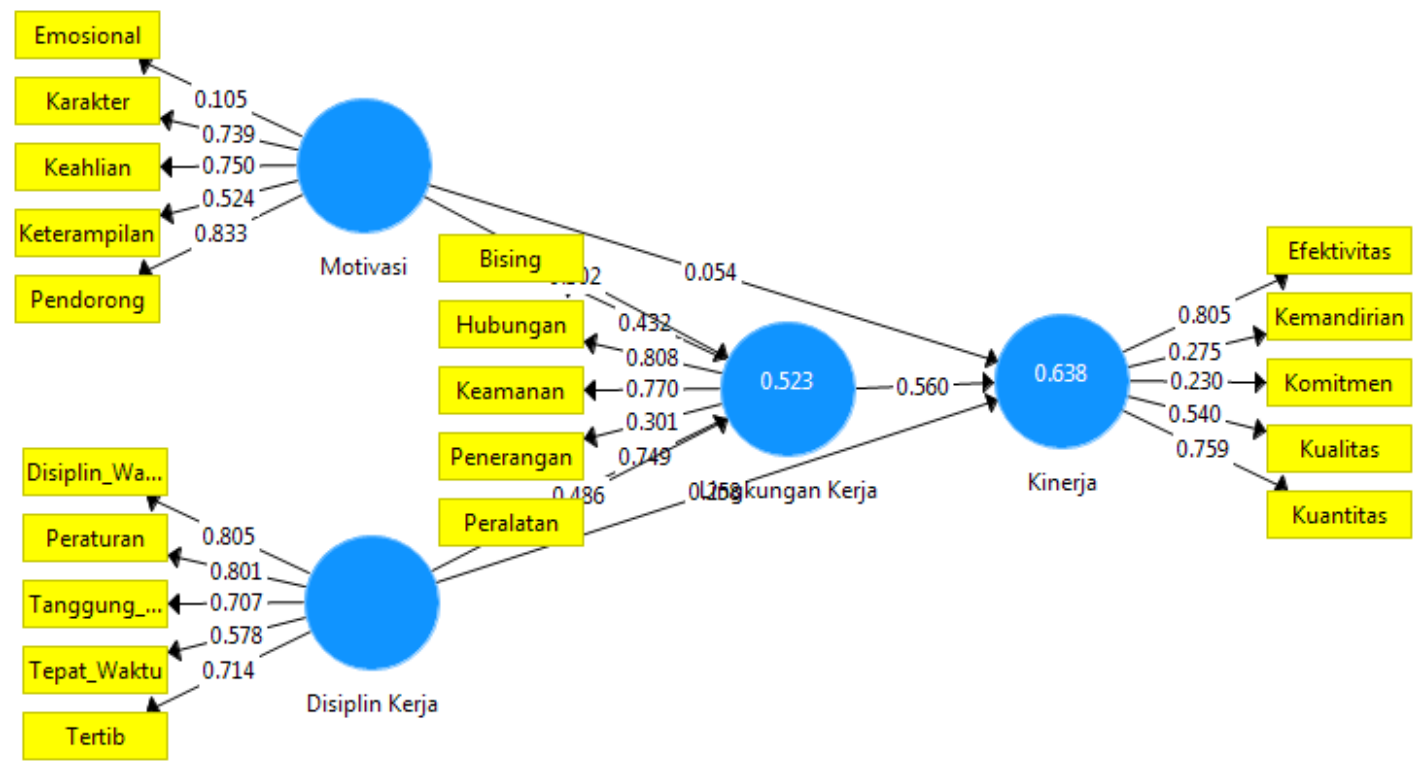

Sumber: Data diolah

Penilaian dalam model PLS mengacu pada hasil perhitungan nilai $R$-Squsre pada tiap variabel laten dependen. Tabel V.10 merupakan hasil estimasi $R$-square dengan menggunakan Smart PLS.

Tabel 5. Nilai $R$-Square

\begin{tabular}{|l|c|}
\hline \multicolumn{1}{|c|}{ Variabel } & $R$-Square \\
\hline Kinerja & 0,640 \\
\hline Lingkungan Kerja & 0,513 \\
\hline
\end{tabular}

Sumber: Data diolah

Berdasarkan uji perhitungan nilai $R$ Square dapat diketahui bahwa dalam penelitian yang telah dilakukan dapat disimpulkan bahwa variabel Kinerja dan Lingkungan kerja dipengaruhi oleh Disiplin dan Motivasi, variabel Kinerja yang dipengaruhi oleh Motivasi, Lingkungan Kerja dan Disiplin.

Berdasarkan tabel hasil perhitungan yang telah dilakukan juga dapat disimpulkan bahwa variabel Motivasi dan Disiplin Kerja berpengaruh terhadap Kinerja Karyawan dengan nilai $R$-Square yaitu sebesar 0,640.
Dengan kata lain dapat disimpulkan bahwa variabilitas konstruk Kinerja yang dapat dijelaskan oleh variabel konstruk Disiplin dan Motivasi adalah sebesar 64\%. Sedangkan $36 \%$ sisanya dipengaruhi oleh variabel yang lain di luar penelitian yang telah dilakukan.

Sedangkan pada hasil perhitungan $R$ Square yang lain dapat diintepretasikan bahwa variabel Motivasi dan Disiplin Kerja berpengaruh terhadap Lingkungan Kerja dengan nilai 0,513 . Hal tersebut dapat berarti bahwa variabilitas konstruk Lingkungan Kerja yang dapat dijelaskan oleh variabel konstruk Disiplin dan Motivasi adalah sebesar $51,3 \%$. Sedangkan sisanya sebesar 48,7\% dipengaruhi oleh variabel yang lain di luar penelitian yang telah dilakukan.

\section{Pengujian Hipotesis}

Estimasi ukuran signifikansi dapat memberikan penjelasan mengenai informasi tentang hubungan antar variabel dalam penelitian yang tengah dilakukan. Pengambilan keputusan mengenai pengaruh 
variabel dalam penelitian mengacu pada hasil perhitungan output result for Path Coefficients. Berikut adalah estimasi untuk pengujian model struktural.

Tabel 6. Output Result for Path Coefficients

\begin{tabular}{|c|c|c|c|c|c|}
\hline & $\begin{array}{c}\text { Original } \\
\text { Sample } \\
(\mathrm{O})\end{array}$ & $\begin{array}{c}\text { Sample } \\
\text { Mean } \\
(\mathrm{M})\end{array}$ & $\begin{array}{c}\text { Standard } \\
\text { Deviation } \\
(\text { STDEV })\end{array}$ & $\begin{array}{c}\text { T-Statistics } \\
(\mid \text { O/STERR } \mid)\end{array}$ & $\begin{array}{c}\text { P- } \\
\text { Values }\end{array}$ \\
\hline $\begin{array}{c}\text { Disiplin } \\
\text { Kerja } \rightarrow \\
\text { Kinerja }\end{array}$ & 0,318 & 0,334 & 0,170 & 1,869 & 0,062 \\
\hline $\begin{array}{c}\text { Disiplin } \\
\text { Kerja } \rightarrow \\
\text { Lingkungan } \\
\text { Kerja }\end{array}$ & 0,485 & 0,491 & 0,141 & 3,452 & 0,001 \\
\hline $\begin{array}{c}\text { Lingkungan } \\
\text { Kerja } \rightarrow \\
\text { Kinerja }\end{array}$ & 0,515 & 0,499 & 0,139 & 3,713 & 0,000 \\
\hline $\begin{array}{c}\text { Motivasi } \rightarrow \\
\text { Kinerja }\end{array}$ & 0,046 & 0,051 & 0,118 & 0,391 & 0,696 \\
\hline $\begin{array}{c}\text { Motivasi } \rightarrow \\
\text { Lingkungan } \\
\text { Kerja }\end{array}$ & 0,295 & 0,290 & 0,126 & 2,332 & 0,020 \\
\hline
\end{tabular}

Sumber: Data diolah

Pengujian secara statistik dalam setiap hubungan yang diperkirakan atau dihipotesiskan dalam PLS dilakukan dengan simulasi. Dalam penelitian ini dilakukan metode bootstrapping terhadap sampel penelitian. Pengujian dengan menggunakna bootstrapping memiliki tujuan untuk meminimalisir ketidak normalan data yang digunakan dalam penelitian. Hasil pengujian dengan menggunakan metode bootstrapping dengan menggunakan PLS diintepretasikan sebagai berikut:

a. Pengujian Hipotesis 1 (Motivasi berpengaruh positif terhadap Kinerja Pegawai di Kantor Regional X Badan Kepegawaian Negara Denpasar)

Hasil perhitungan hipotesis mengenai variabel Motivasi terhadap Kinerja menunjukkan bahwa nilai koefisien jalur sebesar 0,046, nilai t hitung sebesar 0,391, dan P-Value sebesarr 0,696. Dapat disimpulkan bahwa nilai t hitung lebih kecil daripada nilai t tabel $(1,99394)$ dan $P$-Value lebih besar daripada tingkat alpha $(0,05)$.
Dapat diartikan bahwa variabel Motivasi berpengaruh positif namun tidak signifikan, hal ini tidak sesuai dengan hipotesis yang telah dirumuskan bahwa Motivasi berpengaruh positif terhadap Kinerja Pegawai di Kantor Regional X Badan Kepegawaian Negara Denpasar. Kesimpulan yang dapat diambil adalah Hipotesis 1 ditolak.

b. Pengujian Hipotesis 2 (Disiplin Kerja berpengaruh positif terhadap Kinerja pegawai di Kantor Regional X Badan Kepegawaian Negara Denpasar)

Hasil perhitungan hipotesis mengenai variabel Disiplin Kera terhadap Kinerja menunjukkan bahwa nilai koefisien jalur sebesar 0,318, nilai t hitung sebesar 1,869, dan P-Value sebesarr 0,062. Dapat disimpulkan bahwa nilai t hitung lebih kecil daripada nilai t tabel $(1,99394)$ dan P-Value lebih besar daripada tingkat alpha $(0,05)$. Dapat diartikan bahwa variabel Disiplin Kerja berpengaruh positif namun tidak signifikan terhadap Kinerja Pegawai, hal ini tidak sesuai dengan hipotesis yang telah dirumuskan bahwa Disiplin Kerja berpengaruh positif terhadap Kinerja Pegawai di Kantor Regional X Badan Kepegawaian Negara Denpasar. Kesimpulan yang dapat diambil adalah Hipotesis 2 ditolak.

c. Pengujian Hipotesis 3 (Motivasi berpengaruh positif terhadap Lingkungan Kerja di Kantor Regional X Badan Kepegawaian Negara Denpasar)

Hasil perhitungan hipotesis mengenai variabel Motivasi terhadap Lingkungan Kerja menunjukkan bahwa nilai koefisien jalur sebesar 0,295, nilai t hitung sebesar 2,332, dan $P$-Value sebesar 0,020. Dapat disimpulkan bahwa nilai t hitung lebih besar daripada nilai t tabel $(1,99394)$ dan P-Value lebih kecil daripada tingkat alpha $(0,05)$. Dapat diartikan bahwa variabel Motivasi berpengaruh positif dan signifikan terhadap 
Lingkungan Kerja, hal ini sesuai dengan hipotesis yang telah dirumuskan bahwa Motivasi berpengaruh positif terhadap Lingkungan Kerja di Kantor Regional X Badan Kepegawaian Negara Denpasar. Kesimpulan yang dapat diambil adalah Hipotesis 3 diterima.

d. Pengujian Hipotesis 4 (Disiplin Kerja berpengaruh positif terhadap Lingkungan Kerja di Kantor Regional X Badan Kepegawaian Negara Denpasar)

Hasil perhitungan hipotesis mengenai variabel Disiplin Kerja terhadap Lingkungan Kerja menunjukkan bahwa nilai koefisien jalur sebesar 0,485, nilai $\mathrm{t}$ hitung sebesar 3,452, dan P-Value sebesarr 0,001. Dapat disimpulkan bahwa nilai t hitung lebih besar daripada nilai t tabel $(1,99394)$ dan P-Value lebih kecil daripada tingkat alpha $(0,05)$. Dapat diartikan bahwa variabel Disiplin Kerja berpengaruh positif dan signifikan terhadap Lingkungan Kerja, hal ini sesuai dengan hipotesis yang telah dirumuskan bahwa Disiplin Kerja berpengaruh positif terhadap Lingkungan Kerja di Kantor Regional X Badan Kepegawaian Negara Denpasar. Kesimpulan yang dapat diambil adalah Hipotesis 4 diterima.

e. Pengujian Hipotesis 5 (Lingkungan Kerja berpengaruh positif terhadap Kinerja pegawai di Kantor Regional X Badan kepegawaian Negara Denpasar)

Hasil perhitungan hipotesis mengenai variabel Lingkungan Kerja terhadap Kinerja menunjukkan bahwa nilai koefisien jalur sebesar 0,515, nilai t hitung sebesar 3,713, dan P-Value sebesarr 0,000. Dapat disimpulkan bahwa nilai t hitung lebih besar daripada nilai t tabel $(1,99394)$ dan P-Value lebih kecil daripada tingkat alpha $(0,05)$. Dapat diartikan bahwa variabel Lingkungan Kerja berpengaruh positif dan signifikan terhadap Kinerja Pegawai, hal ini sesuai dengan hipotesis yang telah dirumuskan bahwa Lingkungan Kerja berpengaruh positif terhadap Kinerja Pegawai di Kantor Regional X Badan Kepegawaian Negara Denpasar. Kesimpulan yang dapat diambil adalah Hipotesis 5 diterima.

f. Pengujian Hipotesis 6 (Motivasi berpengaruh positif terhadap Kinerja melalui Lingkungan Kerja di Kantor Regional X Badan Kepegawaian Negara Denpasar)

Hasil perhitungan untuk menguji hipotesis keenam mengenai pengaruh variabel Motivasi terhadap Kinerja melalui Lingkungan Kerja mengacu pada tabel berikut:

Tabel 7. Output Result for Specific Indirect Effects

\begin{tabular}{|c|c|c|c|c|c|}
\hline & $\begin{array}{c}\text { Original } \\
\text { Sample } \\
(\mathrm{O})\end{array}$ & $\begin{array}{c}\text { Sample } \\
\text { Mean } \\
(\mathrm{M})\end{array}$ & $\begin{array}{c}\text { Standard } \\
\text { Deviation } \\
(\text { STDEV })\end{array}$ & $\begin{array}{c}\text { T-Statistics } \\
(\mid \text { O/STERR })\end{array}$ & $\begin{array}{c}\text { P- } \\
\text { Values }\end{array}$ \\
\hline $\begin{array}{c}\text { Disiplin } \\
\text { Kerja } \rightarrow \\
\text { Lingkungan } \\
\text { Kerja } \rightarrow \\
\text { Kinerja }\end{array}$ & 0,250 & 0,245 & 0,098 & 2,534 & 0,012 \\
\hline $\begin{array}{c}\text { Motivasi } \rightarrow \\
\text { Lingkungan } \\
\text { Kerja } \rightarrow \\
\text { Kinerja }\end{array}$ & 0,152 & 0,147 & 0,081 & 1,870 & 0,062 \\
\hline
\end{tabular}

Sumber: Data diolah

Berdasarkan tabel tersebut dapat dilihat bahwa pengujian pengaruh tidak langsung variabel Motivasi terhadap Kinerja melalui Lingkungan Kerja memiliki nilai koefisien jalur sebesar 0,152 , nilai t hitung sebesar 1,870, dan P-Value sebesar 0,062. Dapat diartikan bahwa nilai t hitung lebih kecil dibandingkan dengan nilai $\mathrm{t}$ tabel $(1,99394)$ dan P-Value lebih besar dibandingkan dengan nilai alpha $(0,05)$.

Berdasarkan data tersebut dapat disimpulkan bahwa variabel Motivasi berpengaruh positif tetapi tidak signifikan terhadap Kinerja Pegawai melalui Lingkungan Kerja di Kantor Regional X Badan Kepegawaian Negara Denpasar. 
Kesimpulan yang dapat diambil adalah Hipotesis 6 ditolak.

g. Pengujian Hipotesis 7 (Disiplin Kerja berpengaruh positif terhadap Kinerja pegawai melalui Lingkungan Kerja di Kantor Regional X Badan Kepegawaian Negara Denpasar).

Berdasarkan tabel tersebut dapat dilihat bahwa pengujian pengaruh tidak langsung variabel Disiplin Kerja terhadap Kinerja melalui Lingkungan Kerja memiliki nilai koefisien jalur sebesar 0,250 , nilai $\mathrm{t}$ hitung sebesar 2,534, dan P-Value sebesar 0,012. Dapat diartikan bahwa nilai t hitung lebih besar dibandingkan dengan nilai t tabel (1,99394) dan P-Value lebih kecil dibandingkan dengan nilai alpha $(0,05)$. Berdasarkan data tersebut dapat disimpulkan bahwa variabel Disiplin Kerja berpengaruh positif dan signifikan terhadap Kinerja Pegawai melalui Lingkungan Kerja Kantor Regional X Badan Kepegawaian Negara Denpasar. Kesimpulan yang dapat diambil adalah Hipotesis 7 diterima.

\section{Pembahasan}

Motivasi berpengaruh positif dan tidak signifikan terhadap Kinerja Karyawan di Kantor Regional X Badan Kepegawaian Negara Denpasar. Hasil penelitian ini tidak sejalan dengan penelitian yang telah dilakukan oleh Hamid (2014), Paramarta (2018), dan Utomo (2014) yang menyatakan adanya pengaruh positif motivasi terhadap kinerja.

Berdasarkan hasil analisis rata-rata penilaian/jawaban responden terhadap variabel motivasi termasuk dalam kategori tinggi $(3,40-4,19)$. Penilaian tertinggi pada indikator Motivasi yaitu Karakter dengan rata-rata sebesar 3,88. Sedangkan keahlian dengan rata-rata 3,81 dan pendorong dengan rata-rata 3,61. Berdasarkan hasil tersebut dapat disimpulkan bahwa karakter mampu memberikan pengaruh yang tinggi terhadap kinerja karyawan, selanjutnya diikuti oleh keahlian dan pendorong.

Disiplin Kerja berpengaruh positif dan tidak signifikan terhadap Kinerja Pegawai Kantor Regional X Badan Kepegawaian Negara Denpasar. Hal ini tidak sejalan dengan penelitian yang telah dilakukan oleh Paramarta (2018), Utomo (2014), dan Karyawan et al, (2016) yang menyatakan bahwa disiplin kerja berpengaruh positif terhadap kinerja karyawan.

Berdasarkan hasil analisis rata-rata penilaian/jawaban responden terhadap variabel disiplin kerja termasuk dalam kategori tinggi $(3,40-4,19)$. Penilaian tertinggi pada indikator disiplin kerja yaitu disiplin waktu dengan rata-rata sebesar 3,92. Sedangkan tertib dengan rata-rata 3,88 , tanggung jawab dengan rata-rata 3,75 dan peraturan dengan rata-rata 3,73. Berdasarkan hasil tersebut dapat disimpulkan bahwa disiplin waktu mampu memberikan pengaruh yang tinggi terhadap kinerja karyawan, selanjutnya diikuti oleh tertib, tanggung jawab, dan peraturan.

Motivasi berpengaruh positif dan signifikan terhadap Lingkungan Kerja Kantor Regional X Badan Kepegawaian Negara Denpasar. Hal ini sesuai dengan penelitian yang telah dilakukan oleh Utomo (2014) dan Karyawan et al, (2016) yang menyatakan bahwa motivasi berpengaruh positif dan signifikan terhadap lingkungan kerja.

Berdasarkan hasil analisis rata-rata penilaian/jawaban responden terhadap variabel motivasi termasuk dalam kategori tinggi $(3,40-4,19)$. Penilaian tertinggi pada indikator Motivasi yaitu Karakter dengan rata-rata sebesar 3,88. Sedangkan keahlian dengan rata-rata 3,81 dan pendorong dengan rata-rata 3,61. Berdasarkan hasil tersebut 
dapat disimpulkan bahwa karakter mampu memberikan pengaruh yang tinggi terhadap kinerja karyawan, selanjutnya diikuti oleh keahlian dan pendorong.

Disiplin Kerja berpengaruh positif dan signifikan terhadap Lingkungan Kerja Kantor Regional X Badan Kepegawaian Negara Denpasar. Hal ini sesuai dengan penelitian yang telah dilakukan Karyawan et al, (2016).

Berdasarkan hasil analisis rata-rata penilaian/jawaban responden terhadap variabel disiplin kerja termasuk dalam kategori tinggi $(3,40-4,19)$. Penilaian tertinggi pada indikator disiplin kerja yaitu disiplin waktu dengan rata-rata sebesar 3,92. Sedangkan tertib dengan rata-rata 3,88, tanggung jawab dengan rata-rata 3,75 dan peraturan dengan rata-rata 3,73. Berdasarkan hasil tersebut dapat disimpulkan bahwa disiplin waktu mampu memberikan pengaruh yang tinggi terhadap kinerja karyawan, selanjutnya diikuti oleh tertib, tanggung jawab, dan peraturan.

Lingkungan Kerja berpengaruh positif dan signifikan terhadap Kinerja Pegawai Kantor Regional X Badan Kepegawaian Negara Denpasar

Berdasarkan hasil analisis rata-rata penilaian/jawaban responden terhadap variabel Lingkungan Kerja termasuk dalam kategori tinggi $(3,40-4,19)$. Penilaian tertinggi pada indikator Lingkungan Kerja yaitu hubungan dengan rata-rata sebesar 3,97. Sedangkan keamanan dengan rata-rata 3,88, dan peralatan dengan rata-rata 3.91 . Berdasarkan hasil tersebut dapat disimpulkan bahwa lingkungan kerja dapat memberikan pengaruh paling tinggi terhadap kinerja pegawa. Selanjutnya diikuti oleh keamanan dan peralatan.

Motivasi berpengaruh positif dan tidak signifikan terhadap Kinerja Pegawai melalui
Lingkungan Kerja Kantor Regional X Badan Kepegawaian Negara Denpasar

Berdasarkan hasil pengujian hipotesis mengenai pengaruh tidak langsung variabel motivasi terhadap kinerja pegawai melalui lingkungan kerja menunjukkan nilai koefisien jalur sebesar 0,152 dengan nilai t hitung sebesar 1,870, dan P-Value sebesar 0,062. Berdasarkan hasil penelitian tersebut menunjukkan bahwa lingkungan kerja belum dapat menjadi variabel mediasi atau intervening dalam pengaruh motivasi terhadap kinerja karyawan

Disiplin Kerja berpengaruh positif dan signifikan terhadap Kinerja pegawai melalui Lingkungan Kerja Kantor Regional X Badan Kepegawaian Negara Denpasar.

Berdasarkan hasil pengujian hipotesis mengenai pengaruh tidak langsung variabel disiplin kerja terhadap kinerja melalui lingkungan kerja menunjukkan nilai koefisien jalur sebesar 0,250 dengan nilai $\mathrm{t}$ hitung sebesar 2,534, dan P-Value sebesar 0,012. Berdasarkan hasil penelitian tersebut menunjukkan bahwa lingkungan kerja dapat menjadi variabel mediasi atau intervening dalam pengaruh disiplin kerja terhadap kinerja.

\section{KESIMPULAN}

Berdasarkan hasil penelitian yang telah dilakukan dan pembahasan yang telah dipaparkan pada bab sebelumnya, maka dapat ditarik kesimpulan sebagai berikut

1. Berdasarkan hasil perhitungan mengenai uji hipotesis dapat disimpulkan bahwa variabel Motivasi berpengaruh positif tetapi tidak signifikan terhadap Kinerja Pegawai di Kantor Regional X Badan Kepegawaian Negara Denpasar.

2. Berdasarkan hasil perhitungan mengenai uji hipotesis dapat disimpulkan bahwa variabel Disiplin Kerja berpengaruh positif tetapi tidak signifikan terhadap 
Kinerja Pegawai di Kantor Regional X Badan Kepegawaian Negara Denpasar.

3. Berdasarkan hasil perhitungan mengenai uji hipotesis dapat disimpulkan bahwa variabel Motivasi berpengaruh positif signifikan terhadap Lingkungan Kerja di Kantor Regional X Badan Kepegawaian Negara Denpasar.

4. Berdasarkan hasil perhitungan mengenai uji hipotesis dapat disimpulkan bahwa variabel Disiplin Kerja berpengaruh positif dan signifikan terhadap Lingkungan Kerja di Kantor Regional X Badan Kepegawaian Negara Denpasar.

5. Berdasarkan hasil perhitungan mengenai uji hipotesis dapat disimpulkan bahwa variabel Lingkungan Kerja berpengaruh positif dan signifikan terhadap Kinerja Pegawai di Kantor Regional X Badan Kepegawaian Negara Denpasar.

Berdasarkan hasil perhitungan mengenai uji hipotesis dapat disimpulkan bahwa variabel Motivasi berpengaruh positif tetapi tidak signifikan terhadap kinerja pegawai melalui Lingkungan Kerja di Kantor Regional X Badan Kepegawaian Negara Denpasar.

6. Hasil pengujian hipotesis menunjukkan bahwa Disiplin Kerja berpengaruh positif signifikan terhadap Kinerja Pegawai melalui Lingkungan Kerja di Kantor Regional X Badan Kepegawaian Negara Denpasar.

\section{DAFTAR PUSTAKA}

Gardjito, A. H., Musadieq, M. Al, \& Nurtjahjono, G. E. (2014). Pengaruh Motivasi Kerja Dan Lingkungan Kerja Terhadap Kinerja Karyawan (Studi pada Karyawan Bagian Produksi PT. Karmand Mitra Andalan Surabaya). Jurnal Administrasi Bisnis, 13(1), 1-8.

Inbar, N. R. D., Astuti, E. S., \& Sulistyo, M.
C. W. (2018). Pengaruh Lingkungan Kerja Terhadap Disiplin Kerja Dan Semangat Kerja Karyawan ( Studi Pada Karyawan PDAM Kota Malang ). Jurnal Administrasi Bisnis, 58(2), 84-92.

Ingsiyah, H., Haribowo, P., \& Nurkhayati, I. (2019). Pengaruh Lingkungan Kerja Terhadap Motivasi Kerja Karyawan Pada PT. Pupuk Sriwidjaja Palembang, Pusri Pemasaran Daerah (Ppd) Jawa Tengah. Jurnal Admisi Dan Bisnis, 20(1), 83-92.

Leuhery, F., \& Manuhutu, A. J. (2018). Pengaruh Perilaku Kepemimpinan Berorientasi Hubungan, Promosi Jabatan dan Lingkungan Kerja Fisik terhadap Kinerja Pegawai Negeri Sipil Pada Dinas Pendidikan dan Kebudayaan Kabupaten Maluku Tengah. Jurnal Manis, 2(1), 1124.

Mamesah, A. M. ., Kawet, L., \& Lengkong, V. P. . (2016). Pengaruh Lingkungan Kerja, Disiplin Kerja, Dan Loyalitas Kerja Terhadap Kinerja Karyawan Pada LPP RRI Manado Influence Environmental Work, Work Discipline, And Loyalty To Work On The Performance Employees At LPP RRI Manado. Jurnal Emba, 4(3), 600-611.

Marpaung, I. M., Hamid, D., \& Iqbal, M. (2014). Pengaruh Motivasi Dan Disiplin Kerja Terhadap Kinerja Karyawan (Studi Pada Karyawan Rumah Sakit Reksa Waluya Mojokerto). Jurnal Administrasi Bisnis, 15(2), 1-8.

Pangarso, A., \& Susanti, P. I. (2016). Pengaruh Disiplin Kerja Terhadap Kinerja Pegawai Di Biro Pelayanan Sosial Dasar Sekretariat Daerah Provinsi Jawa Barat. Jurnal Manajemen Teori Dan Terapan, 2, 145-160.

Paramarta, W. A., Laswitarni, N. K., Nurani, N. N., \& Wiyandani, N. M. A. (2018). Kepemimpinan, Motivasi Dan Disiplin Kerja Pengaruhnya Terhadap Kinerja Karyawan Joint Operator PT. Wijaya 
Karya (Persero) TBK. - PT. Mirlindo Padu Kencana Pesanggaran Bali. Prosiding Seminar Nasional Hasil Penelitian, 1-19.

Paramarta, W. A., \& Reny, N. K. (2014). Pengaruh Motivasi Dan Kepuasan Kerja Terhadap Intensi Keluar Karyawan. Jurnal Manajemen \& Akuntansi ATIE Triatma Mulya, 20(1), 23-39.

Paramarta, W. A., \& Suastari, N. L. (2018). Employee Engagement Dan Motivasi Pengaruhnya Terhadap Kepuasaan Kerja Dan Kinerja Karyawan Waterbom Bali. Jurnal Forum Manajemen, 16(1), 74-85.

Prihantoro, A. (2012). Peningkatan Kinerja Sumber Daya Manusia Melalui Motivasi, Disiplin, Lingkungan Kerja, Dan Komitmen. Jurnal Value Added, 8(2), 78-98.

Suprihati. (2014). Analisis Faktor-faktor Yang Mempengaruhi Kinerja Karyawan Perusahaan Sari Jati Di Sragen. Jurnal Paradigma, 12(1), 93-112.

Utomo, B. P. C. (2014). Pengaruh Kepemimpinan, Motivasi Kerja, Disiplin Kerja dan Lingkungan Kerja terhadap Kinerja Karyawan dan Dosen STMIK Duta Bangsa Surakarta. Jurnal Sainstech Politeknik Indonusa Surakarta, 1(1), 1324. 